\title{
Pengaruh Profitabilitas Terhadap Harga Saham Pada Jakarta Islamic Index: Struktur Modal Sebagai Variabel Intervening
}

\author{
Ahmad Ulil Albab Al Umar'), Yusvita Nena Arinta ${ }^{2)}$, Saiful Anwar ${ }^{3)}$, Anava Salsa \\ Nur Savitri ${ }^{4)}$, Muhammad Ali Faisal ${ }^{5)}$ \\ ${ }^{1234}$ Fakultas Ekonomi dan Bisnis Islam IAIN Salatiga, ${ }^{5}$ Universitas Gajah Mada \\ Email : ahmadulil.asfebi@gmail.com ${ }^{1)}$, nena@iainsalatiga.ac.id ${ }^{2}$, \\ saifulanwarmieta@iainsalatiga.ac.id ${ }^{3)}$, anavasalsa@gmail.com ${ }^{4)}$, \\ maf.alifaisal@gmail.com ${ }^{5)}$
}

\begin{abstract}
This study aims to analyze the profitability and capital structure of stock prices. The direct effect of profitability illustrated by ROA, ROE, NPM and EPS, and the capital structure proxied by DER on stock prices and the indirect effect of ROA, ROE, NPM, and EPS on stock prices through the Jakarta Islamic Index (JII) capital structure. The population in this study were 30 companies in the Jakarta Islamic Index (JII) for the 2015-2018 period. The results of this study found that ROA and NPM have a negative effect on stock prices. But NPM has a significant effect while ROA is not significant. ROE and EPS are both positive and significant effect on stock prices. The capital structure does not mediate the ROA and NPM variables but mediate the ROE and EPS variables on stock prices

Keyword : Profitability, Capital Structure, Stock Price
\end{abstract}

Abstrak

Penelitian ini bertujuan untuk menganalisis profitabilitas dan struktur modal terhadap harga saham. Pengaruh langsung dari profitabilitas yang digambarkan dengan ROA, ROE, NPM dan EPS, dan struktur modal yang diproksi dengan DER terhadap harga saham dan pengaruh tidak langsung dari ROA, ROE, NPM, dan EPS pada harga saham melalui struktur modal Jakarta Islamic Indeks (JII). Populasi dalam penelitian ini adalah 30 perusahaan di Jakarta Islamic Index (JII) periode 2015-2018. Hasil pada penelitian ini menemukan bahwa ROA dan NPM berpengaruh negative terhadap harga saham. Namun NPM berpengaruh signifikan sedangkan ROA tidak signifikan. ROE dan EPS sama-sama berpengaruh positif dan signifikan terhadap harga saham. Struktur modal tidak memediasi variabel ROA dan NPM namun memediasi variable ROE dan EPS terhadap harga saham.

Kata Kunci : Profitabilitas, StrukturModal, Harga Saham

\section{PENDAHULUAN}

Perkembangan pasar modal syariah ditunjukan dengan meningkatnya indeks saham pada Jakarta Islamic Index (JII). Meskipun prosentase peningkatan indeks saham pada JII lebih besar dari IHSG, peningkatan nilai indeks pada JII namun ternyata tidak bisa berkompetisi pada Indeks Harga Saham Gabungan (IHSG). Fenomena tersebut disebabkan adanya karakteristik yang muncul pada pasar modal syariah, dimana pasar modal syariah menerapkan prinsip, yang bersumber dari nilai epistemologi Islam. Industri pasar modal digunakan emiten untuk mengumpulkan modal. Banyak jenis surat berharga (securities) yang perjualbelikan salah satunya yaitu saham. Saham adalah salah produk yang diperjualbelikan di pasar modal. Produk lain yang diperjualbelikan di pasar modal adalah obligasi dan surat berharga turunan (derivative). Robert Ang (1997) untuk menilai kinerja emiten pada pasar modal mengelompokkan rasio keuangan perusahaan yaitu rasio profitabilitas, rasio aktivitas, rasio likuiditas, rasio solvabilitas dan rasio pasar. Beberapa rasio keuangan yang dapat mempengaruhi harga saham yaitu ROA, ROE, NPM, EPS.

Penelitian ini akan menguji rasio profitabilitas. Profitabilitas merupakan cerminan kemampuan perusahaan untuk memaksimalkan laba dengan semua asset 
yang dimiliki. Semakin tinggi tingkat profitabilitas perusahaan, semakin menunjukan kemapuan perusahaan dalam menghasilkan laba semakin maksimal. Dasar penggunaan rasio profitabilitas yaitu tujuan umum perusahaan adalah untuk memperoleh keuntungan. Tujuan emiten yaitu untuk maksimalisasi labakeuntungan. Tingkat laba emiten diukur dengan rasio profitabilitas. Rasio profitabilitas merupakan ukuran sejauhmana emiten memperoleh profit dan efektivitas manajemen dalam memperoleh laba. Semakin tinggi tingkat profitabilitas maka perusahaan itu dapat dikatakan memiliki prospek bisnis yang menjanjikan dan dapat memberikan tingkat pengembalian dividen yang menguntungkan. Investor tentu dapat menjadikan rasio profitabilitas sebagai kriteria untuk berinvestasi pada emiten tersebut. Peminat saham emiten yang semakin tinggi dapat mendorong kenaikan harga saham dan nilai fundamental saham pada Bursa Efek Indonesia.

Fokus utama pada penilainan kinerja emiten adaalah profitabilitas yang terdapat laporan keuangan. Memaksimalkan keuntungan demi mempertahankan kelangsungan hidup perusahaan. Harga Saham mencerminkan bagian dari keberhasilan kinerja perusahaan. Harga saham yang tinggi menunjukan kinerja perusahaan yang semakin baik. Sehingga menarik minat para investor untuk membeli saham dengan harapan tingkat pengembalian yang tinggi pula. Begitu juga sebaliknya harga saham yang rendah menunjukan kinerja perushaan yang semakin menurun. Sejalan yang diungkap (Hamzah, 2005) menyatakan bahwa secara bersama-sama variabel fundamental dalam profitabilitas berpengaruh signifikan terhadap harga saham Syariah. Rasio profitibilitas emiten dapat diperoleh dari annual report dan ihtisar laporan keungan..

Struktur modal merupakan variansi sumber daya yang dimiliki perusahaan dengan berbagai macam karakteristik. Struktur modal mempunyai peran sebagai pembiayaan semua operasional dan pertumbuhan perusahaan. Indikasi struktur modal dinyatakan optimal jika terciptanya keseimbangan antara resiko dan profit yang di peroleh dalam usaha pencapaian tujuan perusahaan. Oleh karena itu dalam penelitian ini struktur modal secara tidak langsung ikut mempengaruhi harga saham. Dalam hal ini struktur modal sebagai variable intervening yang meperkuat pengaruhnya pada harga saham. Dari uraian latar belakang diatas, peneliti tertarik melakukan penelitian dengan judul "The Effect Of Profitability On Stock Prices With Capital Structure As An Intervening Variable In Jakarta Islamic Index".

\section{KAJIAN TEORI DAN PENGEMBANGAN HIPOTESA \\ Teori Stakeholder}

Teori stakeholder menjelaskan bahwa setiap stakeholder memiliki hak yang sama untuk memperoleh infomasi aktivitas perusahaan sebagai dasar pengambilan keputusan. Investor mengharapkan bahwa emiten pada industry pasar modal melakukan full disclosure atas semua aktivitas perusahaan. Stakeholder juga memiliki hak to choice antara menggunakan atau mengabaikan informasi tersebut (Deegan, 2004) dalam berperilaku pada industri pasar modal.

\section{Profitabilitas}

Menurut (Wulandari, 2017) profitabilitas merupakan rasio kemampuan perusahaan untuk dapat menghasilkan profit bagi emiten. Sejalan dengan definisi tersebut Sartono (2010) menjelaskan bahwa profitabilitas merupakan kemampuan perusahaan dalam menghasilkan profit dalam hubungannya dengan penjualan, baik bentuk total aktiva maupun modal sendiri. 


\section{Harga Saham}

Didefinisikan oleh (Abdul, 2005), harga saham ialah harga di pasar jual beli saham yang terbentuk akibat dari transaksi jual beli antara investor dengan perusahaan. Harga pasar yaitu harga penutupan (closing price) pada saat bursa efek ditutup. Nilai pasar (market value) merupakan perkalian harga pasar outstanding share.

\section{Struktur Modal}

Struktur modal ialah perbandingan atau rasio antara hutang dengan modal sendiri. Struktur modal (Capital structure) (Sudana, 2011) merupakan perbandingan hutang jangka panjang dengan modal sendiri untuk mengukur belanja jangka panjang. Perusahaan yang sudah go public memiliki dana yang lebih besar dan luas dengan pertimbangan menjual sahamnya ke masyarakat luas, sedangkan perusahaan yang tertutup modalnya hanya dari modal sendiri dan utang pihak ketiga (Sugiarto, 2009).

\section{Pengaruh ROA terhadap DER}

Hal ini ditunjukkan (Prasetyo, 2013) yang menemukan bahwa Return On Assets (ROA) perusahaan memberikan pengaruh terhadap Debt to Equity Ratio (DER).

H1 : ROA berpengaruh terhadap DER.

\section{Pengaruh ROE terhadap DER}

Menurut (Wulandari, 2017) Return On Equity berpengaruh terhadap struktur modal pada sector property \& real estate yang terdaftar di Bursa Efek Indonesia.

H2 : ROE berpengaruh terhadap DER

\section{Pengaruh NPM terhadap DER}

Menurut (Wijaya \& Utama, 2014) dalam penelitiannya menemukan bahwa NPM berpengaruh terhadap struktur modal yang diproyeksikan dengan DER.

H3 : NPM berpengaruh terhadap DER

\section{Pengaruh EPS terhadap DER}

Menurut (Dzulqodah \& Mujati, 2016) dalam penelitiannya menemukan ada pengaruh tidak langsung Earning Per Share terhadap Debt to Equity Ratio.

H4 : EPS berpengaruh terhadap DER

\section{Pengaruh DER terhadap Harga Saham}

Terdapat pengaruh antara Debt to Equity Ratio (DER). Menurut (Prasetyo, 2013) mengemukakan bahwa Debt to Equity Ratio memiliki pengaruh signifikan terhadap harga saham. DER sebagai nilai ekuitas dapat menjadi informasi penting dan indikator dari harga saham emiten bagi stakeholder.

H5 : DER berpengaruh terhadap Harga Saham

\section{Pengaruh ROA terhadap Harga Saham}

Menurut (Aminah, Afiati, \& Supriyanto, 2016) dalam penelitiannya menemukan bahwa Return On Assets berpengaruh negative terhadap harga saham pada perusahaan real estate \& property di Bursa Efek Indonesia. Hasil ini juga sejalan dengan (Andrew \& Djuaeriah, 2013) yang menemukan adanya korelasi signifikan antara ROA terhadap harga saham.

H6 : ROA berpengaruh terhadap Harga Saham

\section{Pengaruh ROE terhadap Harga Saham}

(Aminah et al., 2016) mengemukakan bahwa terdapat pengaruh antara ROE terhadap Harga Saham. Bagi para stakeholder rasio ROE menjadi penting untuk dijadikan dalam pengambilan keputusan. 
H7 : ROE berpengaruh terhadap Harga Saham

\section{Pengaruh NPM terhadap Harga Saham}

Terdapat pengaruh antara NPM terhadap Harga Saham. Hal ini diperkuat dalam penelitian (Dini \& Indarti, 2012) menunjukkan NPM berpengaruh terhadap harga saham.

H8 : NPM berpengaruh terhadap Harga Saham

\section{Pengaruh EPS terhadap Harga Saham}

Dalam penelitian (Munggaran, Mukaram, \& Sarah, 2018) menunjukkan ada pengaruh yang signifikan antara EPS terhadap Harga Saham.

H9 : EPS berpengaruh terhadap Harga Saham

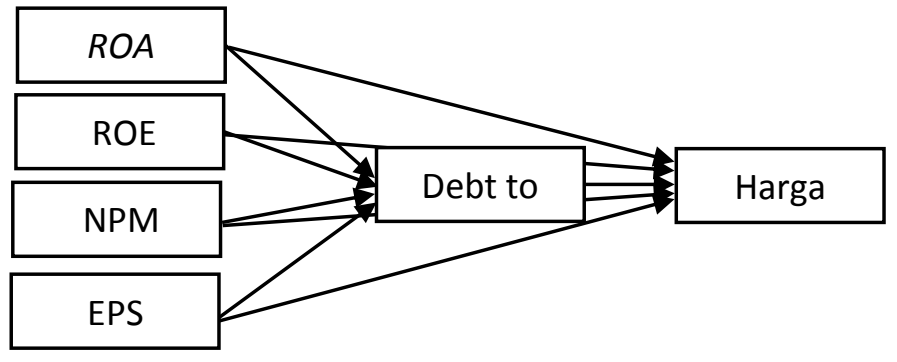

Gambar 1. Kerangka Konseptual Penelitian

\section{METODE PENELITIAN}

Penelitian ini menggunakan metode deskriptif kuantitatif. Populasi dalam penelitian ini ialah semua perusahaan yang terdaftar di Jakarta Islamic Index. Teknik pemilihan Sampel dalam penelitian ini menggunakan purposive sampling dengan kriteria perusahaan yang sudah terdaftar di JII tahun 2016-2018 dan diperoleh sampel 29 perusahaan. Data dalam penelitian ini ialah data sekunder yang didapat dari www.idx.co.id. Teknik analisis data dalam penelitian ini menggunakan analisis jalur atau path analysis. Persamaan regresi berganda dalam penelitian ini ada 2 persamaan sebagai berikut :
Persamaan 1
$: Y=\alpha+\beta 1 \times 1+\beta 2 \times 2+\beta 3 \times 3+\beta 4 \times 4+\beta 5 Z+e$
Persamaan 2

$$
: Z=\alpha+\beta 1 \times 1+\beta 2 \times 2+\beta 3 \times 3+\beta 4 \times 4+e
$$

Keterangan :

$$
\begin{array}{ll}
\mathrm{x} 1 & =\mathrm{ROA} \\
\mathrm{x} 2 & =\mathrm{ROE} \\
\mathrm{x} 3 & =\mathrm{NPM} \\
\mathrm{x} 4 & =\mathrm{EPS} \\
\mathrm{y} & =\text { Harga Saham } \\
\mathrm{z} & =\text { DER } \\
\alpha & =\text { Konstanta } \\
\beta & =\text { Koefisien regresi } \\
\mathrm{e} & =\text { Error }
\end{array}
$$

HASIL DAN PEMBAHASAN

Uji Statistik Deskriptif

Tabel 1. Hasil Uji Statistik Deskriptif

\begin{tabular}{llllll}
\hline \multicolumn{2}{l}{ Descriptive Statistics } & & & & \\
& N & Min & Max & Mean & Std. Deviation \\
\hline ROA & 87 & -5.72 & 46.66 & 9.7284 & 10.11465 \\
ROE & 87 & -14.06 & 135.85 & 18.3964 & 24.66974 \\
\hline
\end{tabular}


INVENTORY : Jurnal Akuntansi Vol. 4 No. 1 April 2020

\begin{tabular}{|c|c|c|c|c|c|}
\hline NPM & 87 & -13.45 & 50.15 & 12.8105 & 10.37612 \\
\hline EPS & 87 & -174.31 & 3028.81 & 423.6520 & 611.72958 \\
\hline DER & 87 & .15 & 3.31 & 1.0243 & .70286 \\
\hline HS & 87 & 376.00 & 55900.00 & 7287.4023 & 10051.17596 \\
\hline Valid N (listwise) & 87 & & & & \\
\hline
\end{tabular}

Berdasarkan tabel diatas rata-rata harga saham sebesar 7287,4023 ini menunjukkan bahwa rata-rata harga saham di perusahaan Jakarta Islamic Index (JII) tahun 2016-2018 sebesar 7287,4023 dengan std devisiasi 10051,17596. Ratarata ROA sebesar 9,7284 artinya rata-rata ROA di perusahaan Jakarta Islamic Index (JII) sebesar 9,7285 dengan std devisiasi 10,11465. Hal ini menunjukkan bahwa ROA di perusahaan JII mempunyai nilai yang kurang begitu menjanjikan. Semakin tinggi ROA maka membuktikan bahwa emiten memiliki kinerja yang efektif.

Nilai rata-rata ROE sebesar 18,3964 dengan std devisiasi sebesar 24,66974, NPM memiliki nilai rata-rata sebesar 12,8105 dengan std devisiasi sebesar 10,37612 dan untuk EPS memiliki rata-rata sebesar 423,6520 dengan std devisiasi sebesar 611,72958. Hal ini menunjukkan perusahan di Jakarta Islamic Index sudah memiliki profitabilitas menengah. Kemudian untuk nilai DER ratarata sebesar 1,0243 dengan std devisiasi 0,70286. Hal ini menunjukkan bahwa rasio modal sendiri dengan hutang perusahaan di Jakarta Islamic Index sangat rendah. Hal ini juga menunjukkan kebanyakan perusahaan di JII memiliki modal sendiri yang besar dibandingkan dengan hutangnya.

\section{Uji Determinasi $\mathbf{R}^{2}$}

Tabel 2. $\mathbf{R}^{2}$ (Test 1)

\begin{tabular}{ll|l|l|l|l}
\hline Model R & R Square & $\begin{array}{l}\text { Adjusted } \\
\text { Square }\end{array}$ & $\begin{array}{l}\text { R } \\
\text { Std. Error of } \\
\text { the Estimate }\end{array}$ & $\begin{array}{l}\text { Durbin- } \\
\text { Watson }\end{array}$ \\
\hline 1 & $.820^{\mathrm{a}}$ & .673 & .652 & 5926.27790 & 1.275 \\
\hline
\end{tabular}

a. Predictors: (Constant), DER, ROA, EPS, NPM, ROE

b. Dependent Variable: HS

Sumber: Data Penelitian, 2020

Berdasarkan table diatas diketahui nilai $\mathrm{R}$ sebesar 0,820 . Hal ini berarti hubungan antara variable independen dengan variable dependen yang kuat. Kemudian nilai Adjusted $R$ Square sebesar 0,652 atau 65,2\%. Hal ini berarti bahwa variable independent dapat menjelaskan hubungannya terhadap variable dependen sebesar $65,2 \%$ sisanya $34,8 \%$ dijelaskan oleh factor lainnya yang diluar penelitian ini.

Tabel 3. $\mathbf{R}^{2}$ (Test 2)

\begin{tabular}{ll|l|l|l|l}
\hline Model R & R Square & $\begin{array}{l}\text { Adjusted } \\
\text { Square }\end{array}$ & $\begin{array}{l}\text { R } \\
\text { Std. Error of } \\
\text { the Estimate }\end{array}$ & $\begin{array}{l}\text { Durbin- } \\
\text { Watson }\end{array}$ \\
\hline 1 & $.475^{\mathrm{a}}$ & .225 & .188 & .63352 & 1.084 \\
\hline
\end{tabular}

a. Predictors: (Constant), EPS, NPM, ROE, ROA

b. Dependent Variable: DER

Sumber: Data Penelitian, 2020

Tabel di atas nilai $\mathrm{R}$ sebesar 0,475. Hal ini berarti hubungan antara variable independen dengan variable dependen yang cukup kuat. Kemudian diperoleh nilai Adjusted R Square sebesar 0,188 atau 18,8\%. Hal ini berarti bahwa variable independen dapan menjelaskan hubungannya terhadap variable dependen 
sebesar $18,8 \%$ sisanya $82,2 \%$ dijelaskan oleh faktor lain diluar dalam penelitian ini.

\section{Uji F}

Tabel 4. Hasil Uji F test

\begin{tabular}{lll|l|l|l|l}
\hline Model & & Sum of Squares & Df & Mean Square & F & Sig. \\
\hline \multirow{2}{*}{1} & Regression & 5843465533.044 & 5 & 1168693106.609 & 33.276 & $.000^{\mathrm{b}}$ \\
\cline { 2 - 8 } & Residual & 2844782349.875 & 81 & 35120769.752 & & \\
\cline { 2 - 8 } & Total & 8688247882.920 & 86 & & & \\
\hline
\end{tabular}

a. Dependent Variable: HS

b. Predictors: (Constant), DER, ROA, EPS, NPM, ROE

Sumber: Data Penelitian, 2020

Berdasarkan hasil uji $\mathrm{F}$ atau simultan diatas didapatkan nilai $\mathrm{F}$ hitung sebesar 33,276 dan nilai signifikansi sebesar 0,000 <0,05. Hasil ini menunjukkan bahwa variable independent secara Bersama-sama berpengaruh terhadap Harga Saham.

\section{Uji t}

Tabel 5. Uji t parsial (Test 1)

\begin{tabular}{|c|c|c|c|c|c|}
\hline \multirow[b]{2}{*}{ Model } & \multicolumn{2}{|c|}{ Unstandardized Coefficients } & \multirow{2}{*}{$\begin{array}{l}\text { Standardized } \\
\text { Coefficients } \\
\text { Beta }\end{array}$} & \multirow[b]{2}{*}{$\mathrm{T}$} & \multirow[b]{2}{*}{ Sig. } \\
\hline & B & Std. Error & & & \\
\hline 1 (Constant) & 2479.439 & 1623.709 & & 1.527 & .131 \\
\hline ROA & -117.729 & 125.280 & -.118 & -.940 & .350 \\
\hline ROE & 285.814 & 49.530 & .702 & 5.771 & .000 \\
\hline NPM & -146.236 & 73.094 & -.151 & -2.001 & .049 \\
\hline EPS & 7.699 & 1.125 & .469 & 6.844 & .000 \\
\hline DER & -676.516 & 1033.037 & -.047 & -.655 & .514 \\
\hline
\end{tabular}

a. Dependent Variable: HS

Sumber: Data Penelitian, 2020

Interpretasi hasil uji di atas yaitu :

1. Return On Assets (ROA) memiliki nilai t hitung sebesar $-0,940<\mathrm{t}$ table serta memiliki nilai signifikan sebesar 0,350 >0,05 pada taraf signifikansi sebesar $5 \%$ atau 0,05. Hal ini mengidentifikasikan bahwa ROA memiliki pengaruh negative dan tidak signifikan terhadap harga saham.

2. Return On Assets (ROE) memiliki nilai t hitung sebesar 5,771 > t table serta memiliki nilai signifikan sebesar $0,000<0,05$ pada taraf signifikansi sebesar $5 \%$ atau 0,05 . Hal ini mengidentifikasikan bahwa ROE memiliki pengaruh positif dan signifikan terhadap harga saham.

3. Net Profit Margin (NPM) mempunyai nilai t hitung sebesar $-2,001<\mathrm{t}$ table dan memiliki nilai signifikan sebesar $0,049<0,05$ pada taraf signifikansi sebesar 5\% atau 0,05. Hal ini mengidentifikasikan bahwa NPM memiliki pengaruh negatif dan signifikan terhadap harga saham.

4. Earning Per Share (EPS) memiliki nilai t hitung sebesar 6,844 > t table serta memiliki nilai signifikan sebesar $0,000<0,05$ pada taraf signifikansi sebesar $5 \%$ atau 0,05. Hal ini mengidentifikasikan EPS memiliki pengaruh positif dan signifikan terhadap harga saham.

5. Debt to Equity Ratio (DER) memiliki nilai t hitung sebesar $-0,655<\mathrm{t}$ table serta memiliki nilai signifikan sebesar $0,514<0,05$ pada taraf signifikansi 
sebesar 5\% atau 0,05. Hal ini mengidentifikasikan bahwa DER memiliki pengaruh negatif dan tidak signifikan terhadap harga saham.

Tabel 6. Uji t parsial (Test 2)

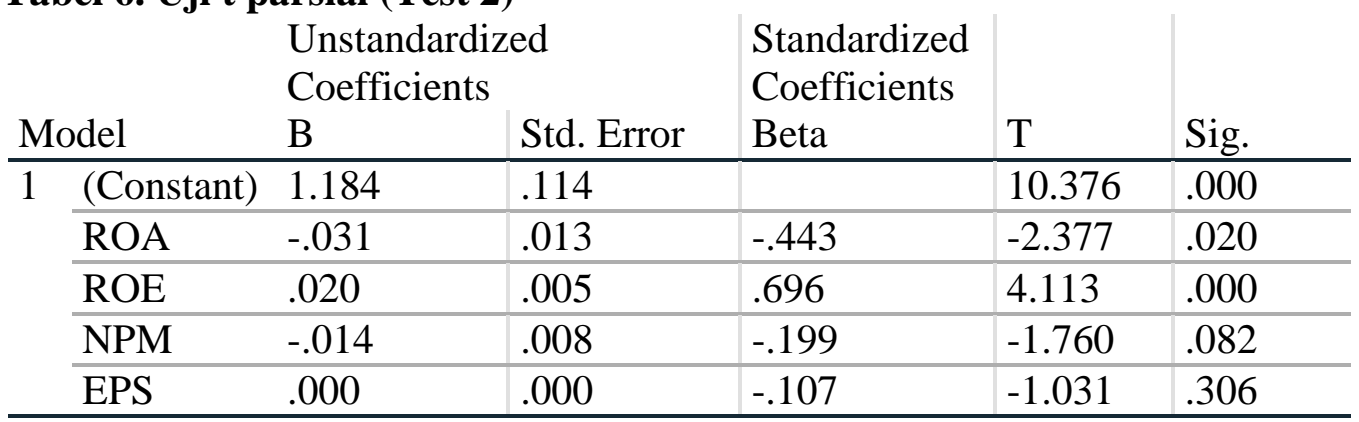

a. Dependent Variable: DER

Sumber: Data Penelitian, 2020

Berdasarkan hasil uji diatas dapat di interpretasikan :

1. ROA memiliki nilai $\mathrm{t}$ hitung $-2,377<\mathrm{t}$ table serta memiliki nilai signifikan sebesar $0,020<0,05$ pada tingkat signifikansi sebesar $5 \%$ atau 0,05. Hal ini mengidentifikasikan bahwa Return On Assets (ROA) memiliki pengaruh negative dan signifikan terhadap struktur modal.

2. Return On Equity (ROE) memiliki nilai t hitung sebesar 4,113 > t table serta memiliki nilai signifikan sebesar $0,000<0,05$ pada taraf signifikansi sebesar 5\% atau 0,05 . Hal ini mengindikasikan bahwa ROE mempunyai pengaruh positif dan signifikan terhadap struktur modal.

3. NPM mempunyai nilai $\mathrm{t}$ hitung $-1,760<\mathrm{t}$ table serta memiliki nilai signifikan sebesar $0,082>0,05$ pada taraf signifikansi sebesar $5 \%$ atau 0,05 . Hal ini mengindikasikan bahwa NPM mempunyai pengaruh negative dan tidak signifikan terhadap struktur modal.

4. Earning Per Share (EPS) memiliki nilai t hitung sebesar $-1,031<\mathrm{t}$ table serta memiliki nilai signifikan sebesar $0,306>0,05$ pada taraf signifikansi sebesar 5\% atau 0,05. Hal mengindikasikan bahwa EPS mempunyai pengaruh negative dan tidak signifikan terhadap struktur modal.

\section{Analisis Jalur atau Path Analysis}

Menggambarkan pengaruh mediasi ditunjukkan dari perkalian koefisien $\mathrm{p}^{2}$ $\mathrm{x} \mathrm{p}^{3}$ (Ghozali, 2013). Untuk menguji signifikansi menggunakan sobel test berikut: $S p^{2} \mathrm{p}^{3}=\sqrt{p 3^{2} S p 2^{2}+p 2^{2} S p 3^{2}+S p 2^{2} S p 3^{2}}$

Menghitung nilai $t$ statistik pengaruh mediasi dengan rumus sebagai berikut :

$$
\mathrm{t}=\frac{p^{2} p^{\mathrm{a}}}{S p^{\mathrm{s}} p^{\mathrm{a}}}
$$

Jika nilai t hitung $>\mathrm{t}$ tabel dengan tingkat signifikansi sebesar 0,05 sebesar 1,66256 maka hal tersebut bisa diartikan terdapat pengaruh mediasi. Berdasarkan uji jalur di SPSS, Menghasilkan model analisis jalur sebagai berikut : Dari Tabel 2 dan Tabel 3 diatas besar nilai e1 $=\sqrt{1-0,673}=0,571$ dan besarnya e $2=\sqrt{1-0,225}=$ 0,880 
Berdasar tabel 5 dan 6 kemudian menghasilkan model :

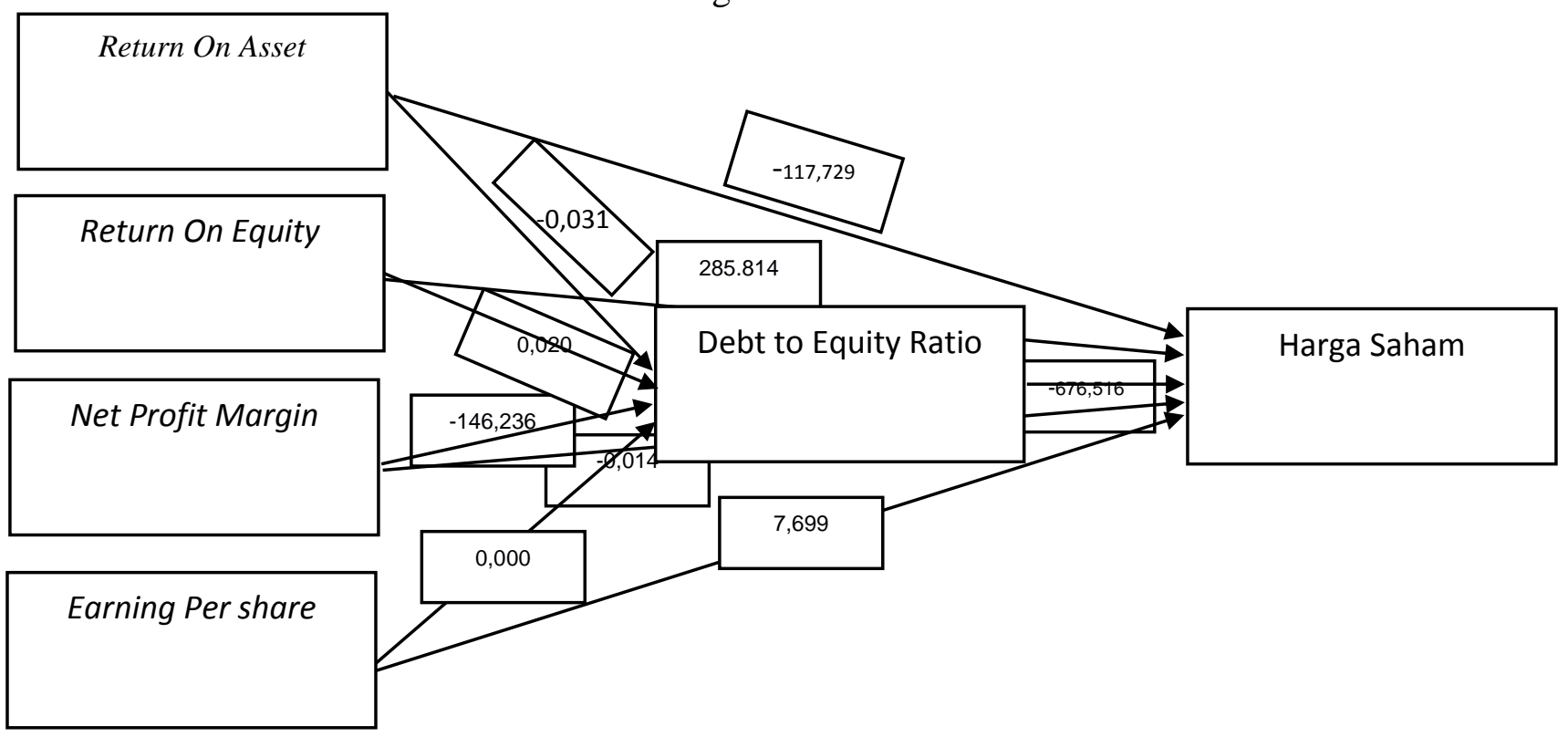

Gambar 2. Model Path Analysis atau Analisis Jalur

Penjelasan gambar di atas adalah sebagai berikut ini :

1. Pengaruh langsung ROA terhadap Harga Saham $=-117,729$

2. Pengaruh langsung ROE terhadap Harga Saham $=285,814$

3. Pengaruh langsung NPM terhadap Harga Saham $=-146,236$

4. Pengaruh langsung EPS terhadap Harga Saham = 7,699

5. Pengaruh tidak langsung antara ROA dengan Harga Saham $=(-0,031) \times(-$ $676,516)=20,971966$,

6. Pengaruh total ROA terhadap Harga Saham $=-117,729+20,971966=$ 96,757004

7. Pengaruh tidak langsung ROE terhadap Harga Saham $=(0,020) \times(-$ $676,516)=-13,53032$

8. Pengaruh total ROE terhadap Harga Saham $=285,814+(-13,53032)=$ 272,28368

9. Pengaruh tidak langsung NPM terhadap Harga Saham $=(-0,014) \times(-$ $676,516)=9,471224$

10. Pengaruh total NPM terhadap Harga Saham $=-146,236+9,471224=-$ 136,764776

11. Pengaruh tidak langsung EPS terhadap Harga Saham $=(0,000) \times(-$ 676,516) $=-676,516$

12. Pengaruh total EPS terhadap Harga Saham $=7,699+(-676,516)=-$ 668,817

\section{HASIL DAN PEMBAHASAN}

ROA memiliki pengaruh negative dan tidak siginifikan. Hasil pengujian $\mathrm{t}$ test pertama nilai koefisien sebesar -117,729 dengan nilai signifikansi sebesar 0,350 lebih besar dari 0,05 . Artinya semakin tinggi nilai ROA maka harga saham belum tentu akan naik dan semakin rendah nilai ROA juga belum tentu akan menaikan harga saham. Perilaku investor terhadap penawaran saham syariah menganggap bahwa ROA tidak dapat untuk membandingkan peluang investasi 
pada jenis industry yang berbeda. ROA hanya dapat digunakan untuk menganalisis perusahaan sejenis sehingga investor menganggap ROA akan mentah sebagai bahan pengambalian keputusan pembelian saham.

ROE berpengaruh positif dan signifikan terhadap harga saham Hasil pengujian $t$ test pertama nilai koefisien sebesar 285,814 dengan nilai signifikansi sebesar 0,000 lebih kecil dari 0,05. Semakin tinggi nilai ROE maka akan akan menaikkan harga saham dan semakin rendah ROE akan menurunkan harga saham. Emiten akan berminat pada saham emiten ketika ROE emiten semakin tinggi. Emiten dipercaya oleh investor mampu mengelola laba bersih menggunakan modal yang diinvestasikan oleh pemegang saham. ROE dapat digunakan oleh calon investor untuk membandingkan dengan emiten lain pada saat akan melakukan pembelian saham. Shareholder Value Creation akan menganggap bahwa ROE merupakan nilai dari emiten sehingga emiten akan mempertimbangkan ROE sebagai indikator profitabilitas sebelum pengambilan keputusan pembelian saham.

NPM berpengaruh negative dan signifikan terhadap harga saham. Hasil pengujian t test pertama nilai koefisien sebesar -146,236 dengan nilai signifikansi sebesar 0,049 lebih kecil dari 0,05. Semakin tinggi NPM maka harga saham akan semakin rendah dan begitu sebaliknya. Kinerja emiten dikatakan tidak produktif karena NPM yang tinggi beluim tentu beban operasional emiten syariah rendah. Investor mengkhawatirkan sistem epistomologi islam belum tentu dapat menekan BOPO emiten syariah. Sampai saat ini memang emiten syariah memiliki kendala menekan biaya operasioanal. Biaya operasional yang tinggi berarti akan menurunkan EPS yang disediakan oleh emiten syariah pada JII sehingga minat investor untuk melakukan pembelian saham syariah menjadi rendah. Minat emiten yang rendah ini direspon negative oleh calon investor sehingga dapat menurunkan harga saham.

EPS berpengaruh positif dan signifikan terhadap harga saham. Hasil pengujian $t$ test pertama nilai koefisien sebesar 7,699 dengan nilai signifikansi sebesar 0,000 lebih kecil dari 0,05. Semakin tinggi earning per share emiten maka akan menaikan harga saham dan semakin rendah earning per share emiten akan menurunkan harga saham emiten. Minar untuk membeli saham emiten syariah akan semakin tinggi ketika earning per share semakin tinggi. Banyaknya minat investor ini yang mendorong harga saham akan semakin tinggi. EPS sebagai pertanda bahwa potensi pendapatan bagi investor jika melakukan pembelian saham emiten syariah. Kemampuan emiten dalam memberikan keuntungan bagi investor pada setiap lembar saham mendorong kenaikan harga saham emiten syariah. EPS yang tinggi maka akan memperoleh respon positif oleh pasar yang kemudian berdampak pada kenaikan harga saham.

Berdasarkan pengujian analisis jalur atau path analysis, untuk variable ROA diperoleh nilai $t$ hitung sebesar lebih kecil daripada t table 1,665 dengan tingkat signifikansi sebesar 0,05, maka dapat disimpulkan bahwa struktur modal tidak dapat memediasi pengaruh ROA terhadap harga saham. Berdasarkan pengujian analisis jalur atau path analysis, untuk variable ROE diperoleh nilai $\mathrm{t}$ hitung sebesar lebih besar daripada t table 1,665 dengan tingkat signifikansi sebesar 0,05, maka dapat disimpulkan bahwa struktur modal dapat memediasi pengaruh ROE terhadap harga saham.

Struktur modal tidak dapat memediasi NPM terhadap kenaikan harga saham. Hasil pengujian analisis jalur atau path analysis, variabel NPM didapat 
nilai t hitung lebih kecil daripada t table 1,665 dengan tingkat signifikansi sebesar 0,05. Semakin tinggi DER belum tentu dapat dikatakan dapat menaikkan harga saham syariah pada JII. Penggunaan utang oleh emiten syariah dalam justru akan dianggap oleh investor sebagai penambahan Beban operasional emiten syariah. Minat investor untuk membeli saham syariah akan turun seiring sejalan dengan anggapan bahwa NPM yang tersedia akan diprioritaskan emiten untuk membiayai utang yang digunakan untuk operasional perusahaan dalam memperoleh laba.

Berbeda dengan hasil mediasi NPM terhadap harga saham pada JII, Struktur modal justru dapat memediasi EPS pada harga saham. Berdasarkan pengujian analisis jalur atau path analysis, untuk variable EPS diperoleh nilai $\mathrm{t}$ hitung sebesar lebih besar daripada t table 1,665 dengan tingkat signifikansi sebesar 0,05. Investor menganggap bahwa EPS yang tinggi jika DER emiten semakin tinggi. DER yang tinggi dianggap oleh investor bahwa emiten mampu memberikan EPS yang tinggi bagi pemegang saham. Kewajiban yang dimiliki emiten justru akan menurunkan beban pajak sehingga EPS yang diperoleh akan akan semakin tinggi yang kemudian pasar akan merespon positif yang berdampak pada kenaikan harga saham emiten syariah.

\section{KESIMPULAN DAN SARAN}

ROA memiliki pengaruh negative dan tidak signifikan terhadap harga saham, NPM berpengaruh negative dan signifikan terhadap harga saham, sedangkan untuk ROE dan EPS sama-sama berpengaruh positif dan signifikan terhadap harga saham. Kemudian struktur modal tidak mampu memediasi variable ROA dan NPM namun mampu mediasi variable ROE dan EPS terhadap harga saham. Diharapkan juga kepada penulis selanjutnya supaya dapat menambah variable maupun periode yang diteliti sehingga penelitian ini dapat menajadi lebih sempurna lagi.

\section{DAFTAR PUSTAKA}

Abdul, H. (2005). Analisis Investasi. Edisi Kedua. Jakarta: Salemba Empat.

Aminah, N., Afiati, R., \& Supriyanto, A. (2016). Pengaruh Deviden Per Share, Return on Equity, Net Profit Margin, Return on Investment Dan Return on Asset Terhadap Harga Saham Pada Perusahaan Real Estate Dan Property Yang Terdaftar Di Bursa Efek Indonesia Periode Tahun 2011-2013. Journal Of Accounting, 2(2), 1-19. https://doi.org/10.1111/jgh.14027

Andrew, L., \& Djuaeriah. (2013). The Determinants of Ther Stock Price in Indonesia Publicy Listed Transportation Industry. Jurnal Business and Information, 1, 45-49.

Dzulqodah, M., \& Mujati, Y. (2016). Pengaruh Earning Per Share Dan Price Earning Ratio Terhadap Debt To Equity Ratio Dan Harga Saham Pada Perusahaan Sektor Makanan Dan Minuman Di Bursa Efek. Jurnal EKSIS, $X I(1)$.

Ghozali, I. (2013). Analisis Multivariate SPSS 25. Semarang.

Hamzah, A. (2005). Analisa Ekonomi Makro, Industri dan Karakteristik Perusahaan terhadap Beta Saham Syariah. Simposium Nasional Akuntansti VIII.

Munggaran, A., Mukaram, M., \& Sarah, I. S. (2018). Pengaruh Earning Per Share (Eps) Terhadap Harga Saham (Kasus Pada Perusahaan Sektor Property, Real Estate, and Building Construction Yang Terdaftar Di Bursa Efek Indonesia 
Periode 2011-2015). Jurnal Riset Bisnis Dan Investasi, 3(2), 1. https://doi.org/10.35697/jrbi.v3i2.929

Prasetyo, R. (2013). Pengaruh Profitabilitas Terhadap Harga Saham Perusahaan Di Sektor Manufaktur Periode 2009-2013 Dengan Menggunakan Struktur Modal Sebagai Variabel Intervening. Journal of Chemical Information and Modeling, 53(9), 1689-1699. https://doi.org/10.1017/CBO9781107415324.004

Sudana, I. (2011). Manajemen Keuangan Perusahaan Teori fan Praktek. Jakarta: Erlangga.

Sugiarto. (2009). Struktur Modal, Struktur Kepemilikan Perusahaan, Permasalahan Keagenan dan Informasi Asimetri. Yogyakarta: Graha Ilmu.

Wijaya, I. ., \& Utama, I. . (2014). Pengaruh Profitabilitas, Struktur Aset dan Pertumbuhan Penjualan terhadap Struktur Modal serta Harga Saham. EJournal Akuntansi Universitas Udayana, 6, 514-530.

Wulandari, R. (2017). Pengaruh Profitabilitas Terhadap Harga Saham dengan Struktur Modal Sebagai Variabel Intervening pada Sektor Property\&Real Estate di Bursa Efek Indonesia Periode 2012-2016. Jurnal Atmajaya. 